\title{
PERILAKU SUBJEK DALAM BAHASA KEMAK KABUPATEN BELU NUSA TENGGARA TIMUR
}

\author{
I Wayan Budiarta \\ Program Pascasarjana Universitas Warmadewa \\ email: budy4rt4@yahoo.com
}

\begin{abstract}
Abstrak
Penelitian ini bertujuan mengidentifikasi perilaku subjek bahasa Kemak Kabupaten Belu Nusa Tengara Timur. Sifat perilaku subjek bahasa Kemak $(\mathrm{BKm})$ diidentifikasi dengan pengetesan terhadap argumen yang ditengarai sebagai subjek. Data penelitian adalah data lisan dan tulisan berupa klausa atau kalimat yang diperoleh melalui metode linguistik lapangan, yaitu elisitasi langsung dan didukung dengan teknik wawancara. Informan yang dipilih merupakan penutur asli. Hasil penelitian menunjukkan bahwa subjek BKm memiliki sifat-perilaku: (1) muncul pada posisi praverbal pada struktur kanonis, (2) adverbia dan penegasi dapat disisipkan di antara subjek sebagai argumen praverbal dengan predikat, (3) subjek dapat direlatifkan, (4) antara subjek dan predikat dapat disisipi penjangka kambang, (5) subjek dapat direfleksifkan, (6) argumen yang bukan subjek (objek langsung dan objek tak langsung) dapat dinaikkan menjadi subjek melalui mekanisme penaikan (raising), (7) subjek dapat difokuskan dengan menghadirkan pemarkah fokus te 'yang' yang hadir langsung setelah subjek, dan (8) subjek dapat dikontrol.
\end{abstract}

Kata kunci: bahasa Kemak, subjek, perilaku

\section{SUBJECT CHARACTERISTICS OF THE KEMAK LANGUAGE IN BELU REGENCY, EAST NUSA TENGGARA}

\begin{abstract}
This study aims to identify subject characteristics of the Kemak language in Belu Regency, East Nusa Tenggara. The subject characteristics are identified by testing the arguments predicted as a subject. The data were spoken and written data in the form of clauses or sentences collected through the field linguistic method, using direct elicitation supported by interviews. The selected informants were native speakers. The findings show that the subject in the Kemak language has the following characteristics. (1) The subject appears in the pre-verbal position in the canonical structure. (2) An adverb and a negation marker can be inserted between the subject as a pre-verbal argument and the predicate. (3) The subject can be relativized. (4) A floating quantifier can be inserted between subject and predicate. (5) The subject can be made reflexive. (6) Non-subject arguments (direct and indirect objects) can be raised to be a subject through the raising mechanism. (7) The subject can be focused through the presence of the focus marker te 'that' which appears directly after the subject. (8) The subject can be controlled.
\end{abstract}

Keywords: Kemak language, subject, characteristics

\section{PENDAHULUAN}

Bahasa Kemak (BKm) merupakan satu dari empat bahasa lokal yang dituturkan oleh masyarakat di kabupaten Belu, Nusa Tenggara Timur. Keempat bahasa tersebut adalah bahasa Tetun yang dituturkan oleh 
Suku Tetun, bahasa Bunak yang dituturkan oleh suku Bunak atau Marae, bahasa Dawan yang dituturkan oleh Suku Dawan, dan bahasa Kemak yang dituturkan oleh suku Kemak. Walaupun terdapat empat bahasa yang dituturkan oleh masyarakat di kabupaten Belu, namun masyarakat dari penutur bahasa yang berbeda tersebut hidup berdampingan dengan damai dan bahkan dapat ditemukan penutur satu bahasa mampu berkomunikasi dengan bahasa yang bukan bahasa suku mereka. Jika melihat jumlah penutur, bahasa Kemak merupakan bahasa dengan jumlah penutur yang paling sedikit jika dibandingkan dengan bahasa lainnya, yaitu sekitar 3000 orang yang bermukim di dua desa, yaitu desa Umaklaran dan desa Sadi.

Sejauh ini baru terdapat tiga penelitian yang mengkaji bahasa Kemak, yaitu (1) Stevens (1967), (2) Sadnyana dkk. (1996), dan Mandaru, dkk. (1998). Penelitian pertama yang mengkaji bahasa Kemak dilaksanakan oleh Stevens (1967). Sesungguhnya penelitian Stevens dilakukan pada tahun 1961, namun hasil penelitiannya baru dipublikasikan pada jurnal Anthropological Linguistic tahun 1967. Sebagai penelitian awal yang mengkaji BKm, penelitian Stevens (1967) tersebut hanya memuat daftar 200 kata BKm (daftar Swadesh). Berdasarkan daftar Swadesh tersebut Stevens menyatakan bahwa BKm dikelompokkan ke dalam bahasa Austronesia. Dalam jurnal Anthropological Linguistic tersebut tidak terdapat penjelasan lebih lanjut mengenai alasan secara teoretis terkait pengelompokkan $\mathrm{BKm}$ dikelompokkan ke dalam bahasa Austronesia selain penentuan dengan daftar Swadesh tersebut.

Penelitian dedua yang mengkaji BKm dilakukan oleh Sadnyana dkk. (1996). Hasil penelitian tersebut telah mengungkapkan beberapa aspek kebahasaan, yaitu fonologi, morfologi, dan sintaksis. Penelitian terhadap ketiga aspek tersebut hanya bersifat deskriptif yang hanya mampu memberikan deskripsi awal dan belum menyentuh secara tegas hakikat subjek, Lebih jauh, penjelasan yang diberikan terhadap subjek belum menguraikan perilaku subjek secara tipologis. Subjek hanya diidentifikasi berdasarkan pola kanonik atau tata urutan katanya saja tanpa melakukan pengetesan lebih lanjut terhadap hakikat subjek atau kesubjekkan BKm.

Penelitiaan ketiga yang mengkaji BKm dilakukan oleh Mandaru dkk. (1998). Penelitian tersebut mengungkap beberapa aspek morfologi dan sintaksis BKm yang menitikberatkan pada pengungkapan sistem morfologi dan sintaksis BKm. Di samping itu, penelitian ini juga menyinggung sistem fonologi. Hasil penelitian tersebut hanya melakukan deskripsi yang meliputi konstituen dan tata urut kata tanpa pembahasan lebih lanjut mengenai relasi gramatikal. Hasil penelitian Mandaru dkk. (1998) mengungkapkan bahwa BKm memiliki tata urutan kanonik SVO. Tata urutan kanonik SVO BKm dapat dilihat pada contoh berikut ini.

(1) $A u(S)$ a (P) ika (O)

1T makan ikan

'Saya makan ikan'

(2) Romo (S) seru (P) tais $(O)$

3J tenun kain

'Mereka menenun kain'

(3) Lain (S) ele lika (P) manu (O)

Suami Poss pelihara ayam

'Suaminya memelihara ayam'

(Mandaru, 1998: 66-76)

Ketiga klausa di atas menunjukkan bahwa BKm memiliki pola urutan kanonik SVO. Subjek (S) kalimat di atas adalah au 'saya, romo 'mereka', dan lain ele 'suaminya'. Predikat (P) kalimat adalah a 'makan', seru 'menenun', dan lika 'memelihara'. Sebaliknya, objek (O) kalimat adalah ika 'ikan', tais 'kain', dan manu 'ayam'. 
Hasil penelitian Sadnyana dkk. (1996) dan Mandaru dkk. (1998) menunjukkan bahwa penjelasan tentang hakikat subjek belum diuraikan secara tegas.Kedua hasil penelitian tersebut juga tidak menjelaskan lebih jauh mengenai alternasi struktur kanonik dan relasi gramatikal BKm. Ketika membahas tentang subjek sebuah bahasa tentunya sangat terkait dengan relasi gramatikal karena subjek merupakan relasi gramatikal inti. Secara umum, hasil penelitian Sadnyana dkk. (1996) dan Mandaru dkk. (1998) hanya bersifat struktural-lahiriah. Hasil penelitian Mandaru dkk. (1998) hanya mendaftarkan contoh-contoh dan penjelasan maknanya. Hasil Penelitian Sadnyana dkk. (1996) dan Mandaru dkk. (1998) belum mendasarkan kajiannya dengan menggunakan pendekatan tipologi bahasa untuk melihat perilaku subjek secara khusus.

Mengacu pada hasil penelitian yang diuraikan di atas menunjukkan bahwa penelitian terhadap BKm telah dilakukan, namun penelitian tersebut belum mengungkapkan secara jelas tentang sifat perilaku subjek atau kesubjekkan $\mathrm{BKm}$. Penelitian sebelumnya tersebut mendasarkan identifikasi terhadap subjek berdasarkan pola kanonis atau tata urutan kata saja. Seperti diketahui pengetesan terhadap subjek atau kesubjekkan secara lintas bahasa dapat dilakukan dengan beberapa cara selain denga pola kanonis atau tata urutan kata. Pembahasan tentang subjek pada satu sisi merupakan hal yang sangat menarik dan pada sisi lain juga dapat dikatakan cukup rumit. Salah satu pemicu kerumitan tersebut adalah perilaku gramatikal dan tipologi suatu bahasa. Perilaku gramatikal bahasa yang beragam dan tipologi bahasa yang berbeda dari satu bahasa dengan bahasa lain menyebabkan pengertian dan penetapan tentang subjek memunculkan fenomena yang terus dapat diperdebatkan.

\section{METODE}

Penelitian ini menggunakan ancangan penelitian deskriptif yang bersifat kualitatif. Penerapan metode deskriptif yang bersifat kualitatif dinilai sangat tepat karena bertujuan menggambarkan data bahasa secara alamiah. Data alamiah penelitian ini dikumpulkan berdasarkan fakta yang ada atau fenomena bahasa yang memang secara empiris digunakan oleh penutur $\mathrm{BKm}$ tanpa mempertimbangkan benar salah secara preskriptif (Djajasudarma, 1993:8). Data penelitian merupakan data lisan dan tulisan berupa klausa atau kalimat $\mathrm{BKm}$ yang diperoleh dengan menerapkan metode lingustik lapangan, yaitu elisitasi langsung dan didukung dengan teknik wawancara (Mithun, 2001). Teknik elisitasi langsung dilaksanakan dengan cara mengumpulkan data bahasa yang diawali dengan menyiapkan daftar tanyaan, baik berupa kata, frasa, klausa, maupun kalimat. Sementara itu, teknik wawancara dilaksanakan setelah data diperoleh melalui teknik elisitasi yang bertujuan mengklarifikasi data yang telah diperoleh. Informan yang dipilih berjumlah 5 orang yang merupakan penutur asli BKm, dewasa, dan memiliki kemampuan komunikasi yang baik. Data klausa atau kalimat yang telah terkumpul selanjutnya diklasifikasikan berdasarkan permasalahan yang dikaji, yaitu terkait dengan identifikasi subjek melalui beberapa pengujian terhadap argumen yang ditengarai sebagai subjek. Data yang telah diklasifikasikan tersebut kemudian dianalisis dengan menggunakan metode agih (metode distribusional) (Sudaryanto,1993:15). Selain teknik dasar bagi unsur langsung (BUL), dalam analisis data juga diterapkan teknik lanjutan, yaitu teknik ganti dan teknik sisip. Teknik ganti berfungsi untuk mengetahui kadar kesamaan kelas atau kategori terganti dengan unsur pengganti (Sudaryanto, 1993: 48). Teknik sisip digunakan untuk mengetahui kadar keeratan unsur-unsur dalam 
sebuah konstruksi kalimat (Sudaryanto, 1993: 64). Dengan penggunaan teknik sisip ini diharapkan dapat diketahui kadar keeratan unsur-unsur yang disisipi. Hasil analisis dirangkum dengan menggunakan metode metode informal, yaitu metode penyajian hasil analisis data yang disajikan dalam bentuk paparan menggunakan kata-kata biasa (bahasa verbal).

\section{HASIL DAN PEMBAHASAN Sifat Perilaku Subjek Bahasa Kemak}

Pembahasan tentang subjek diawali dengan uraian beberapa pendapat yang dikemukakan oleh para ahli terkait konsepsi dan sifat-perilaku subjek sebelum dibahas lebih terperinci mengenai sifatperilaku subjek yang terdapat dalam BKm.Beragamnya pendapat para ahli ini disebabkan oleh perilaku gramatikal bahasa yang beragam dan tipologi bahasa yang berbeda dari satu bahasa dengan bahasa lain sehingga menyebabkan pengertian dan penetapan tentang subjek memunculkan fenomena yang terus dapat diperdebatkan.

Kridalaksana (1993:204) mengungkapkan bahwa subjek merupakan bagian dari sebuah klausa/kalimat yang berwujud nomina atau frasa nominal yang menandai apa yang dikatakan oleh pembicara. Konsep tentang subjek sering sekali disalahartikan dengan fungsi-fungsi yang bersifat semantis dan pragmatis.Sejatinya subjek merupakan aspek sintaksis. Subjek dalam setiap klausa atau kalimat mempunyai peranan yang sangatsignifikan untuk menjadikan klausa/kalimat lebih utuh atau sempurna (Palmer, 1994:2). Lebih jauh, Palmer (1994:2) mengungkapkan bahwa subjek merupakan apa yang dibicarakan atau dikatakan tentang sesuatu yang ada. Verhaar (1996: 166) menjelaskan bahwa subjek merupakan apa yang diuraikan oleh verba yang menempati posisi predikat atau apa yang mengalami kejadian yang diartikan oleh verba dalam posisinya sebagai predikat.
Comrie (1983:101) menyatakan bahwa hakikat asal subjek adalah adanya saling keterkaitan antara agen dan topik. Secara lintas bahasa subjek itu merupakan agen dan topik. Subjek dapat dikatakan agen karena terkait dengan fungsi-fungsi semantis, sedangkan subjek dapat dikatakan topik atau tema karena terkait dengan fungsi-fungsi pragmatis.Pendapat lain tentang sifat perilaku subjek dasar dikemukakan juga oleh Keenan (1976: 312-324). Subjek dasar (selanjutnya disebut subjek) mempunyai ciri-ciri dan sifat perilaku khas yang dikelompokkan menjadi empat, yakni (1) sifat-perilaku otonomi, (2) sifat-perilaku pemarkah kasus, (3) peran semantis, dan (4) dominasi langsung (immediate dominance). Subjek berdasarkan peran semantis dapat ditengarai, yaitu (a) subjek biasanya mengungkapkan agen (dari tindakan) jika hanya terdapat satu argumen, (b) subjek biasanya mengungkapkan frasa tujuan (addresssephrase) bentuk imperatif, (c) subjek biasanya memperlihatkan posisi, pemarkah kasus, dan persesuaian verba dengan FN penyebab dalam jenis kalimat kausatif yang paling dasar. Sifat-perilaku dominasi langsung merupakan sifat perilaku subjek yang langsung didominasi oleh simpul dasar kalimat (Keenan, 1976: 312-324). Keempat perilaku khas subjek tersebut bukanlah nilai mutlak. Mungkin saja perilaku tersebut tidak cocok dengan perilaku bahasa tertentu.

Jika mengacu kepada teori Tata Bahasa Leksikal Fungsional (TLF), subjek gramatikal (yang selanjutnya disebut SUBJ) merupakan sesuatu yang bersifat universal. SUBJ merupakan fungsi gramatikal yang memiliki properti [+ inti], sebagaimana juga OBJ. Pada konstruksi intransitif, satu-satunya argumen inti sekaligus merupakan SUBJ. Hal ini merupakan implikasi dari dekomposisi leksikal bahwa setiap predikat harus memiliki subjek. SUBJ adalah fungsi tertinggi dalam struktur fungsi gramatikal yang ber- 
sifat obligatoris (Arka, 2003: 4-5). Dalam konstruksi transitif terdapat dua argumen inti sehingga perlu dilakukan pengetesan terhadap argumen itu yang manakah yang berfungsi sebagai SUBJ dan yang juga berfungsi sebagai OBJ.

Artawa (1998: 15) mengungkapkan secara lintas bahasa, properti SUBJ bervariasi antara satu bahasa dan bahasa lain. Meskipun demikian, terdapat kesamaan properti SUBJ, misalnya argumen verba transitif yang berperilaku sama dengan argumen intransitif. Subjek merupakan relasi gramatikal sehingga penentuan subjek itu sendiri hendaknya didasarkan pada perilaku gramatikal. Dalrymple (2001: 17 - 19) mengungkapkan bahwa terdapat beberapa alat uji untuk menentukan subjek atau kesubjekkan, seperti persesuaian (agreement), honorifikasi (honorification), nonkoreferensi subjek (subject noncoreference), dan peluncuran penjangka kambang (launching float quantifier). Keempat sifat-perilaku subjek yang dikemukakan oleh Keenan (1976:312-324) dan oleh Dalrymple (2001: 17 - 19) tidak seluruhnya dapat digunakan untuk melakukan pengetesan subjek BKm.

Basaria (2013: 141) dalam artikelnya yang membahas pentopikalan dalam Bahasa Pakpak Diari mengungkapkan bahwa secara universal sulit menentukan subjek sebuah kalimat yang disebabkan karena beragamnya konstruksi dan posisi subjek dari setiap bahasa. Kesulitan dalam menentukan subjek dapat dilihat pada Bahasa Latin karena bahasa tersebut tidak mementingkan posisi subjek. Sejauh nomina itu bertanda $\mathrm{N}+$ /us/dalam sebuah kalimat maka nomina tersebut adalah subjek dari kalimat itu, tanpa mempersoalkan posisinya (free word order). Song (2001: 44; Yusdi, 2008:39) dalam Basaria (2013: 141) menyebutkan bahwa penanda seperti ini dikenal dengan penanda kasus (case marking) dalm bentuk morfologis. Basaria (2013:141) menambahkan bahwa bahasa Inggris merupakan bahasa yang bertipologi S-V-O sehingga bahasa tersebut menonjolkan subjek sehingga subjek hadir secara obligatoris.

Berdasarkan hasil analisis subjek BKm memiliki memiliki sifat-perilaku atau properti: (1) subjek BKm muncul pada posisi praverbal pada struktur kanonis, (2) adverbia dan penegasi dapat disisipkan di antara subjek dengan predikat, (3) subjek dapat direlatifkan, (4) antara subjek dan predikat dapat disisipi penjangka kambang, (5) subjek dapat direfleksifkan, (6) argumen yang bukan subjek dapat dinaikkan fungsinya menjadi subjek melalui mekanisme penaikan (raising), (7) subjek dapat difokuskan dengan menghadirkan pemarkah fokus ' $t e$ ' dan (8) subjek dapat dikontrol. Uraian lebih rinci terkait sifat perilaku atau properti tersebut disajikan di bawah ini.

\section{Subjek BKm Muncul pada Posisi Pra- verbal pada Struktur Kanonis}

Klausa BKm memiliki struktur kanonis atau pola kanonis SVO (A-V-P). Struktur kanonis tersebut menunjukkan bahwa subjek BKm muncul pada posisi praverbal atau berada di sebelah kiri predikat (mendahului predikat). Argumen inti yang mengisi posisi subjek menempati posisi praverbal (posisi kiri verba) pada klausa intransitif tersaji pada contoh berikut ini.

(1) $A u \quad a$ 1TG makan

'Saya makan'

(2) Ina la de basar Ibu pergi Prep pasar 'Ibu pergi ke pasar'

(3) Atmas senua mai dase Kupang Orang DEF datang Prep Kupang 'Orang itu datang dari Kupang'

Klausa (1) - (3) di atas menunjukkan bahwa klausa tersebut memiliki satu argumen dan juga menunjukkan bahwa argumen inti menempati posisi praverbal atau berada di sebelah kiri predikat. Argumen 
inti au 'saya' pada klausa (1) berada di sebelah kiri predikat yang ditempati verba $a$ 'makan' (praverbal). Subjek ina 'ibu' pada klausa (2) menempati posisi sebelum predikat yang diisi verba la 'pergi'. Pada klausa (3) argumen inti atmas senua 'orang itu' menempati posisi sebelum predikat yang ditempati verba mai 'datang'. Kelima argumen inti pada klausa (1) - (3) yang berada di sebelah kiri predikat secara sintaksis merupakan subjek. Klausa (1) (3) menunjukkan bahwa struktur kanonikal pada klausa intransitif $\mathrm{BKm}$ hanya menghadirkan subjek pada posisi praverbal atau sebelum verba. Selain predikat yang ditempati verbal, predikat klausa intransitif BKm juga dapat ditempati oleh predikat nonverbal. Klausa intransitif dengan predikat nonverbal dapat dilihat pada contoh di bawah ini.

(4) Au-ng ina-ng guru
1TG-Lig adik-Lig guru
'Adik saya guru'
(5) Hine senua koet
Wanita DEF cantik
'Wanita itu cantik'
(6) Ita-ng ana-ng telu
2JM-Lig anak-Lig tiga

'Anak kita tiga'

(7) Busa senua de uma
Kucing DEF Prep rumah
'Kucing itu di rumah'

Klausa (4) - (7) di atas merupakan klausa intransitif yang ditempati oleh predikat nonverbal yang terdiri atas satu argumen dan predikat.Argumen inti aung inag 'ibu saya' pada klausa (4) menempati posisi sebelah kiri predikat nonverbal (nomina) guru 'guru'. Pada klausa (5), argumen inti hine senua 'wanita itu' berada pada posisi sebelah kiri predikat nonverbal (adjektiva) koet 'cantik'. Argumen inti itang anag 'anak kita' pada klausa (6) menempati posisi di sebelah kiri predikat nonverbal (numeralia) telu 'tiga'. Pada klausa (7), argumen inti busa senua 'kucing itu' menempati posisi di sebelah kiri predikat nonverbal (adverbial) de uma 'di rumah'. Contoh klausa (4) - (7) menunjukkan bahwa argumen inti pada klausa intransitif dengan predikat nonverbal menempati posisi di sebelah kiri predikat secara sintaksis berfungsi subjek. Dengan demikian, argumen inti pada klausa intransitif, baik yang ditempati oleh predikat verbal (klausa 1-3) maupun nonverbal (klausa 4-7), merupakan satusatunya posisi argumen inti yang secara sintaksis berfungsi sebagai subjek.

Mengacu kepada struktur kanonik, klausa intransitif BKm menunjukkan bahwa posisi argumen inti berada di sebelah kiri predikat (praverbal). Bagaimanakah struktur kanonik pada klausa transitif, baik ekatransitif maupun dwitransitif dalam BKm. Berikut ini disajikan uraiannya.

(8) Mane senua meu hine senua Laki-laki DEF cium wanita DEF 'Laki-laki itu mencium wanita itu'

(9) Au-ng ina-ng ala podi ua baru 1TG-Lig ibu-Lig beli APL 3TG baju

'Ibu saya membelikan dia baju'

Klausa (8) di atas merupakan klausa ekatransitif BKm. Terdapat dua argumen inti pada klausa tersebut yang secara semantis berperan sebagai aktor dan undergoer. Argumen inti mane senua 'laki-laki itu' pada klausa (8) secara semantis berperan sebagai agen, sedangkan argumen inti hine senua 'wanita itu' pada klausa (8) secara semantis berfungsi sebagai tema (tm). Argumen inti 'mane senua 'laki-laki itu' (klausa 8) yang menduduki posisi sebelum predikat (praverbal) secara sintaksis merupakan subjek. Klausa (9) d di atas merupakan klausa dwitransitif BKm. Terdapat tiga argumen inti yang terdapat dalam klausa tersebut. Ketiga argumen inti setiap klausa tersebut adalah aung inag 'ibu saya', ua 'dia', dan baru 'baju' pada klausa (9). Argumen inti yang menempati posisi di sebelah kiri predikat praverbal 
pada klausa (9) terdiri atas argumen inti aung inag 'ibu saya' (klausa 9) yang secara sintaksis merupakan subjek. Dari uraian tersebut dapat disimpulkan bahwa subjek dalam BKm hanya dapat muncul pada posisi sebelah kiri predikat (praverbal), baik predikat verbal maupun predikat nonverbal pada klausa intransitif BKm.

\section{Adverbia dan Penegasi dapat Disisipkan di antara Subjek sebagai Argumen Pra- verbal dengan Predikat}

Selain dengan pola kanonis, pengetesan terhadap subjek BKm dapat pula dilakukan dengan penyisipan adverbial (ADV) yang disisipkan di antara argumen inti yang menempati posisi praverbal dan predikat pada klausa BKm yang berupa pemarkah kala. Pemarkah kala seperti na'arua 'kemarin' dan matamai mata 'besok pagi' dapat disisipkan di antara argumen inti yang berada di sebelah kiri predikat dan predikat. Penyisipan adverbial pada klausa intransitif BKm terlihat pada contoh di bawah ini.

(10) Au hali de uma

1TG pulang Prep rumah'

'Saya pulang ke rumah'

(11) Au bairua hali de uma 1TG Adv pulang Prep rumah' 'Saya lusa pulang ke rumah'

Klausa (10) merupakan klausa intransitif yang terdiri atas satu argumen inti yang menempati posisi praverbal dan predikat dalam klausa tersebut dan klausa belum disisipi adverbial di antara satu-satunya argumen inti dan predikat. Sebaliknya, klausa (11) merupakan klausa intransitif $\mathrm{BKm}$ yang telah disisipi oleh adverbial di antara argumen inti dan predikat. Argumen inti au 'saya' pada klausa (10) merupakan satu-satunya argumen inti yang terdapat dalam klausa tersebut yang secara sintaksis berfungsi sebagai subjek. Pada klausa (11), adverbial bairua 'lusa' disisipkan di antara argumen inti au 'saya' dan predikat lali 'pulang'.
Data berikut menyajikan pengetesan subjek pada klausa transitif, baik klausa ekatransitif maupun klausa dwitransitif.

(12) Atmas senua tutu au Orang DEF pukul 3TG 'Orang itu memukul saya'

(13) Ina ala podi ua baru Ibu beli APL 3TG baju 'Ibu membelikan dia baju'

(14) Atmas senua na'arua tutu au Orang DEF Adv pukul 3TG 'Orang itu kemarin memukul saya'

(15) Ina matamai ala podi ua baru Ibu Adv beli APL 3TG baju 'Ibu besok pagi membelikan dia baju'

Klausa (12) merupakan klausa ekatransitif BKm yang belum disisipi adverbial yang terdiri atas dua argumen inti, yaitu atmas senua 'orang itu' dan au 'saya' Klausa (13) adalah klausa dwitransitif dalam BKm. Klausa tersebut terdiri atas tiga argumen inti, yaitu ina 'ibu', $u a$ 'dia', dan baru 'baju'. Pada klausa (14), adverbial na'arua 'kemarin' disisipkan di antara argumen inti atmas senua 'orang itu' dan predikat tutu 'pukul'. Adverbial matamai mata 'besok pagi' disisipkan di antara argumen inti ina 'ibu' dan predikat ala 'beli' pada klausa (15). Dengan demikian, argumen inti pada setiap klausa (12) dan (15) yang berada pada posisi praverbal secara sintaksis merupakan subjek. Hasil analisis di atas menunjukkan bahwa adverbial dapat disisipkan di antara argumen inti yang berada pada posisi praverbal dan predikat.

Di samping menempati posisi antara argumen praverbal dan predikat, adverbial dalam BKm juga dapat menempati posisi sebelum argumen praverbal. Berikut disajikan klausa BKm dengan adverbial yang menempati posisi sebelum argumen praverbal.

(16) Na'arua ua liu asu senua Kemarin 3TG kejar anjing DEF 'Kemarin dia mengejar anjing itu' 
(17) Matamai ina ala podi ua baru Besok ibu beli APL 3TG baju 'Besok ibu membelikan dia baju'

Klausa (16) dan (17) menunjukkan bahwa adverbia dalam BKm dapat menempati posisi di awal sebuah klausa/ kalimat atau menempati posisi sebelum argumen praverbal yang secara gramatikal argumen tersebut berfungsi sebagai subjek.

Di samping dengan penyisipan adverbial, pengetesan subjek BKm dapat juga dilakukan dengan penegasian. Kalimat negatif memiliki konstruksi yang menggunakan pengingkar dengan tujuan pengingkaran (Alwi, dkk. 2000: 378). Selain beberapa pengetesan kesubjekan seperti yang telah disajikan di atas, pengetesan kesubjekan BKm juga dapat dilakukan dengan penegasian.Berikut disajikan bentuk penegasian dalam $\mathrm{BKm}$.
(18) Au-ng ana-ng ti la 1SG-Lig anak-Lig NEG pergi
isikola na'arua
sekolah kemarin

'Anak saya tidak pergi ke sekolah kemarin'

(19) $O$ ti ber enu kopi 2TG NEG suka minum kopi 'Engkau tidak suka minum kopi'

Data (18) dan (19) di atas merupakan kalimat negatif BKm. Kluasa tersebut menunjukkan bahwa penegasiti 'tidak' berada di antara argumen inti pada posisi praverbal yang secara gramatikal berfungsi sebagai subjek dengan verba, baik pada kalimat intransitif maupun kalimat transitif. Dengan demikian, kehadiran penegasi $t i$ 'tidak' yang berada di posisi antara argumen inti yang hadir pada posisi praverbal secara (gramatikal) sintaksis berfungsi sebagai subjek.

\section{Subjek dapat Direlatifkan}

Perelatifan merupakan salah satu strategi yang dapat digunakan untuk menguji apakah sebuah argumen dapat dikategorikan sebagai subjek. Kenyataan menunjukkan bahwa tidak semua bahasa dapat merelatifkan relasi gramatikalnya. Untuk memeroleh gambaran yang jelas mengenai strategi perelatifan terkait dengan subjek atau kesubjekan BKm, berikut ini ditampilkan sejumlah data.

(20) Atmas senua mudu de kursi Orang DEF duduk Prep Kursi 'Orang itu duduk di kursi'

(21) Mane senua au-ng ka'ak Laki-laki DEF 1TG-Lig kakak 'Laki-laki itu kakak saya'

(22) Atmas ne bourung senua mudu Orang REL Adj DEF duduk de kursi

Prep Kursi

'Orang yang gemuk itu duduk di kursi'

(23) Mane ne betu bola senua Laki-laki REL tendang bola DEF au-ng $k a^{\prime} a k$ 1TG-Lig kakak

‘Laki-laki yang menendang bola itu kakak saya'

Klausa (20)- (21) merupakan klausa intransitif BKm. Satu-satunya argumen inti yang hadir di awal klausa atau di sebelah kiri predikat semuanya dapat direlatifkan. Frasa nomina (FN) atmas senua 'orang itu' pada klausa (20) muncul di posisi sebelah kiri predikat mudu'duduk' yang secara semantis berfungsi sebagai agen. Pada klausa (21), frasa nominal mane senua 'laki-laki itu' berada di posisi sebelah kiri predikat nonverbal (nominal) aung ka'ak 'kakak saya'. Hasil perelatifan klausa (20) dan (21) tersaji pada klausa (22) dan (23). Satu-satunya argumen inti yang hadir pada posisi awal atau sebelum predikat dapat direlatifkan dengan permarkah relatif ne 'yang'. Hasil analisis klausa intransitif di atas menunjukkan bahwa subjek gramatikal klausa tersebut yang secara semantis berfungsi, baik sebagai agen maupun pasien, dapat direlatifkan 
dan hasil perelatifan tersebut tersaji pada klausa (22) dan klausa (23). Di samping strategi perelatifan pada klausa intransitif $\mathrm{BKm}$, data menyajikan perelatifan yang terdapat pada klausa transitif BKm.

(24) Hine senua meu mane sепua Wanita DEF cium laki-laki DEF

'Wanita itu mencium laki-laki itu'

(25) Atmas senua ala podi ana senuabaru Orang DEF beli APL anak DEF baju 'Orang itu membelikan anak itu baju'

(26) Hine ne koet senua mеи

Wanita REL Adj DEF cium

mane senua

laki-laki DEF

'Wanita yang cantik itu mencium laki-laki itu'

(27) Atmas ne ara senua ala podi Orang REL berdiri DEF beli APL ana senua bara anak DEF baju

'Orang yang berdiri itu membelikan anak itu baju'

Terdapat dua argumen inti yang hadir pada klausa (24) dan tiga argumen inti pada klausa (25). Argumen inti hine senua 'wanita itu' pada klausa (24) dan atmas senua 'orang itu' pada klausa (25) yang secara sintaksis berfungsi sebagai subjek yang hadir di awal atau sebelum predikat dapat direlatifkan dengan hadirnya pemarkah relative ne'yang'. Hasil perelatifan argumen inti yang secara sintaksis berfungsi sebagai subjek tersaji pada klausa (26) dan (27). Dengan demikian, apabila terdapat sebuah argumen yang menempati posisi sebelum predikat dan argumen tersebut dapat direlatifkan, maka argumen tersebut merupakan subjek

\section{Penjangka Kambang dapat Disisipkan di antara Subjek dan Predikat}

Penjangka kambang BKm yang berfungsi untuk menunjukkan jumlah kolektif adalah mamu 'semua'. Dalam kaitannya dengan pengetesan subjek, penjangka kambang dapat menentukan apakah sebuah FN dapat dikategorikan sebagai subjek atau tidak. Apabila penjangka kambang tersebut tetap mengacu pada FN yang sama, FN tersebut adalah subjek. Sebaliknya, jika penjangka kambang tidak mengacu kepada FN yang berfungsi sebagai subjek, FN tersebut bukan subjek. Untuk mengetahui kesubjekan BKm, berikut disajikan contoh klausa yang menempatkan penjangka mamu 'semua' 'semua' setelah subjek dalam klausa BKm.

(28) Renu mamu la de Masyarakat semua pergi Prep kantor desa kantor desa 'Masyarakat semua pergi ke kantor desa'

(29) Imi mamu selo bea

2JM semua bayar pajak tonang sea saba tahun satu sekali

'Kami semua membayar pajak satu tahun sekali'

Klausa (28) menunjukkan bahwa posisi penjangka kambang mamu 'semua' berada pada posisi antara satu-satunya argumen dan predikat pada klausa intransitif. Penjangka kambang mamu 'semua' mengacu pada FN praverbal yang juga merupakan satu satunya argumen dalam klausa intransitif. Dengan demikian, penjangka kambang mamu 'semua' hanya dapat ditempatkan pada posisi setelah FN praverbal pada klausa intransitif $\mathrm{BKm}$, yang merupakan subjek gramatikal. Sementara itu, klausa (29) juga menunjukkan bahwa penjangka kambang muncul antara argumen preverbal dengan predikat. Penjangka kambang mamu 'semua' pada klausa (29) mengacu pada FN praverbal yang juga merupakan argumen subjek pada klausa tersebut.

\section{Subjek dapat Direfleksifkan}

Agen atau pelaku merupakan bagian yang berfungsi sebagai pengontrol FN refleksif. Salah satu bahasa yang menem- 
patkan agen atau pelaku sebagai pengontrol FN adalah bahasa Inggris. Selain bahasa Inggris, bahasa Bali juga merupakan salah satu bahasa yang menempatkan agen sebagai pengontrol perefleksifan (lihat Artawa, 1998:18). Artawa (1998:18) juga menambahkan bahwa agen menjadi pengontrol perefleksifan merupakan kebenaran umum. Bentuk refleksif BKm diungkapkan dengan bentuk $d u$ ' $u k$ 'diri' dan juga dapat ditambahkan dengan kata lolog 'sendiri' yang berfungsi untuk mempertegas bentuk refleksif BKm. Penggunaan bentuk $d u^{\prime} u k$ lolog 'diri sendiri' pada klausa refleksif BKm disajikan pada contoh berikut
(30) Au tutu du'uk lolog 1TG pukul diri sendiri 'Saya memukul diri sendiri'
(31) Ua basa du;uk lolog 3TG tampar diri sendiri 'Dia menampar diri sendiri'
(32) Roma neu du'uk lolog 3JM lihat diri sendiri 'Mereka melihat diri sendiri'

Contoh klausa (30) - (32) merupakan klausa refleksif BKm. Pada ketiga klausa tersebut agen au 'saya' pada klausa (30), ua 'dia' pada klausa (31), dan roma 'mereka' pada klausa (32) merupakan subjek gramatikal klausa yang bersangkutan. Bentuk refleksif yang diungkapkan dengan kata $d u$ 'uk lolog 'diri sendiri' dikontrol oleh agen. Dengan demikian, dapat disimpulkan bahwa agen dalam BKm berfungsi untuk mengontrol perefleksifan.

\section{Argumen yang bukan Subjek dapat Dinaikkan Fungsinya menjadi Subjek melalui Mekanisme Penaikan (raising)}

Fungsi gramatikal yang dapat dinaikkan menjadi subjek dalam BKm adalah fungsi gramatikal objek melalui mekanisme pemasifan. Karena tidak memiliki afiks yang dilekatkan pada verba untuk membentuk konstruksi pasif, maka pemasifan BKm dilakukan dengan meka- nisme pemasifan analitik, yaitu dengan menggunakan pemarkah toma 'dapat'. Contoh berikut adalah klausa BKm yang memperlihatkan proses penaikan argumen yang bukan subjek menjadi subjek.
(33) a. Ua betu mane senua
3TG tendang laki-laki DEF
'Dia menendang laki laki itu'
b. Mane senua toma betu
Laki-laki DEF dapat tendang
dase ua
Prep 3TG
'Laki-laki itu ditendang oleh dia'
(34) a. Ina ala podi ali baru
Ibu beli APL adik baju
'Ibu membelikan adik baju'
b. Baru toma ala ina odi ali
Baju dapat beli ibu Prep adik
'Baju dibeli ibu untuk adik'
c. Ali toma ala baru dase ina
Adik dapat beli baju Prep ibu
'Adik dibelikan baju oleh ibu'

Klausa (33a) merupakan klausa ekatransitif $\mathrm{BKm}$ yang dibangun oleh argumen subjek $u a$ 'dia' dan argumen objek langsung mane senua 'laki-laki itu'. Klausa (33b) menunjukkan bahwa proses penaikan argumen objek langsung mane senua 'laki-laki itu' dapat dilakukan sehingga menempati posisi subjek. Berbeda dengan klausa (33a), klausa (34a) merupakan klausa dwitransitif yang dibangun oleh argumen ina 'ibu' yang berfungsi sebagai subjek, argumen ali 'adik' yang berfungsi sebagai objek tak langsung, dan argumen baru 'baju yang berfungsi sebagai objek langsung. Klausa (34b) merupakan hasil dari proses penaikan argumen objek langsung baru 'baju' pada klausa (34a) menjadi argumen yang secara gramatikal berfungsi sebagai subjek. Klausa (34b) juga menunjukkan bahwa argumen objek langsung dapat dinaikkan menjadi subjek gramatikal. Sementara, klausa (34c) menunjukkan bahwa argumen objek tak langsung dapat dinaikkan menjadi subjek gramatikal. Dengan demikian, 
berdasarkan pembahasan di atas dapat disimpulkan bahwa penaikan juga dapat digunakan untuk menentukan subjek atau kesubjekan BKm.

\section{Subjek dapat Difokuskan (Pemfokusan)}

Pengetesan lebih lanjut terhadap subjek BKm dapat pula dilakukan dengan pemfokusan. Pemarkah fokus yang terdapat dalam BKm adalah te. 'yang'. Subjek pada klausa intransitif dan transitif dapat difokuskan dengan pemarkah fokus te 'yang' sehingga argumen klausa, baik intransitif maupun transitif yang memiliki properti dapat difokuskan tersebut dapat diasumsikan berfungsi sebagai subjek karena hanya argumen yang muncul sebelum predikat yang dapat difokuskan. Berikut ini disajikan klausa yang mengandung pemfokusan subjek.

(35) Hine koet senua te huri de Wanita cantik DEF FOK tari Prep kantor desa kantor desa

'Wanita cantik itu menari di kantor desa'

(36) Roma te basa anag senua 3JM FOK tampar anak DEF 'Mereka menampar anak itu'

(37) Ina te ala ua buku de basar Ibu FOK beli 3SG buku Prep pasar 'Ibu membelikan dia buku di pasar'

Klausa (35) - (37) merupakan klausa pemfokusan BKm. Pada klausa intransitif (35), argument hine koet senua 'wanita cantik itu' yang menempati posisi sebelum predikat diikuti langsung oleh pemarkah fokus te 'yang'. Argumen klausa ekatransitif roma 'mereka' pada klausa (36) yang menempati posisi sebelum predikat juga langsung diikuti oleh pemarkah fokus te 'yang'. Demikian halnya pada klausa dwitransitif (37), argumen ina 'ibu' yang menempati posisi sebelum predikat juga langsung diikuti oleh pemarkah fokus te yang'. Klausa (35) - (37) menunjukkan bahwa argumen pada setiap klausa tersebut diikuti oleh pemarkah fokus te 'yang'. Pemarkah fokus te 'yang' tersebut secara langsung mengikuti dan sekaligus memarkahi argumen yang menempati posisi sebelum predikat yang ditempati oleh verba. Dengan demikian, pemfokusan merupakan salah satu cara yang dapat digunakan untuk menentukan subjek $\mathrm{BKm}$.

\section{Subjek dapat Dikontrol}

Kontrol juga dapat digunakan sebagai salah satu alat untuk menguji subjek atau kesubjekan dalam BKm. Kontrol dalam $\mathrm{BKm}$ dapat dicermati pada klausa yang disajikan berikut ini.
(38) a. Au gesa ele au-ng 1TG coba cari 1TG-Lig her de Kupang istri Prep Kupang 'Saya mencoba mencari istri saya di Kupang'
b. Au gesa [_ele au-ng 1TG coba [_cari 1TG-Lig her de Kupang] istri Prep Kupang] 'Saya mencoba mencari istri saya di Kupang'
c. Au gesa [*au ele au-ng 1TG coba [*1TG cari 1TG-Lig her de Kupang] istri Prep Kupang] 'Saya mencoba mencari istri saya di Kupang'

(39) a. Ua gesa do 3TG coba lempar au odi batu 1TG Prep batu 'Dia mencoba melempar saya dengan batu'
b. Ua gesa [_do 3TG coba [_lempar au odi batu] 1TG Prep batu] 'Dia mencoba melempar saya dengan batu'
c. Ua gesa 3TG coba [*3TG lempar 


\author{
au odi batu] \\ 1TG Prep batu] \\ 'Dia mencoba melempar saya den- \\ gan batu'
}

Argumen au 'saya' pada klausa (38a) di atas dapat dikontrol seperti terlihat pada klausa (38b). Hal yang serupa juga dapat dilihat pada klausa (39). Argumen ua 'dia' pada klausa (39a) di atas juga dapat dikontrol (lihat klausa 39b). Mengacu kepada strukturnya, klausa (38b) dan (39b) adalah klausa yang berterima. Dengan demikian, au 'saya' pada klausa (38) dan ua 'dia' pada klausa (39) merupakan subjek klausa tersebut. Melihat posisinya, subjek yang dikontrol pada klausa (38) dan (39) berada sebelum verba atau praverbal. Subjek au 'saya' dan ua 'dia' menempati posisi sebelah kiri verba kontrol gesa'coba'. Klausa tersebut menjadi tidak gramatikal apabila subjek menempati posisi sebelah kanan verba kontrol, seperti terlihat pada klausa (38c) dan (39c).

\section{SIMPULAN}

Berdasarkan penjelasan di atas dapat disimpulkan bahwa subjek BKm memiliki sifat-perilaku bahwa subjek BKm muncul pada posisi praverbal pada struktur kanonis. Artinya bahwajika dalam sebuah konstruksi klausa terdapat argumen yang menempati posisi preverbal, maka argumen tersebut dapat dipastikan sebagai subjek. Subjek BKm juga dapat disisipi oleh adverbia dan penegasi yang artinya jika terdapat adverbia dan penegasi yang ditempatkan diantara argumen praverbal dan predikat, maka argumen tersebut dapat dipastikan adalah subjek. Pengujian selanjutnya adalah dengan mekanisme perelatifan, maksudnya bahwa sebuah argumen yang menempati posisi sebelum predikat dan argumen tersebut dapat direlatifkan dengan pemarkah relatif $n e$, maka argumen tersebut merupakan subjek. Sifat perilaku berikutnya adalah dengan penyisipan penjangka kambang mamu 'semua' yang artinya bahwa jika di antara argumen praverbal dan predikat dapat disisipi penjangka kambang, maka argumen tersebut dapat dipastikan sebagai subjek. Pengujian selanjutnya terhadap subjek dilakukan dengan perefleksifan. Artinya bahwa jika bentuk refleksif yang diungkapkan dengan kata $d u^{\prime} u k$ lolog 'diri sendiri' dapat dikontrol oleh argument tersebut, maka argumen tersebut merupakan subjek. Lebih jauh, pengujian terhadap subjek dilakukan dengan melihat apakah argumen yang bukan subjek dapat dinaikkan fungsinya menjadi subjek melalui mekanisme penaikan, jika bisa maka argumen tersebut adalah subjek. Sifat perilaku subjek juga dapat amati dengan pemfokusan, artinya subjek dapat difokuskan dengan menghadirkan pemarkah fokus ' $t e$ ' sehingga argumen tersebut dapat dikatakan sabagai subjek. Pengujian terakhir adalah subjek BKm dapat dicermati dengan mekanisme kontrol. Artinya bahwa jika argumen tersebut dapat dikontrol, maka argument tersebut dipastikan subjek

\section{UCAPAN TERIMA KASIH}

Artikel ini disarikan dari disertasi yang berjudul Tipologi Sintaksis Bahasa Kemak pada Prgram Pascasarjana Universitas Udayana Denpasar. Ucapan terima kasih peneliti ditujukan kepada Prof. Drs. Ketut Artawa, M.A., Ph.D. selaku Promotor, Prof. Dr. Aron Meko Mbete dan Dr. Made Sri Satyawati, S.S., M.Hum. selaku Kopromotor I dan II. Peneliti juga mengucapkan terima kasih kepada Dewan Penguji Disertasi yang telah memberikan saran dan masukan yang konstruktif. Ucapan terima kasih peneliti juga ditujukan kepada Direktur DP2M DIKTI yang telah mendanai penelitian ini melalui Hibah Disertasi Doktor.

\section{DAFTAR PUSTAKA}

Arka, I Wayan. 2003. Balinese Morphosyntax: A Lexical-Functional Approach. Canberra: Pacific Lingustics. 
Artawa, Ketut 1998. "Ergativity and Balinese Syntax". Dalam NUSA Vol. 42-44. Jakarta : Pusat Kajian Bahasa dan Budaya.

Basaria, Ida. 2013, “Pentopikalan dalam Bahasa Pakpak Diari" Dalam LITERA Vol. 13 No. 1. Yogyakarta: Universitas Negeri Yogyakarta

Blake, Barry J. 1990. Relational Grammar. London: Routledge.

Budiarta, I Wayan. 2013. “Struktur Klausa dan Tipologi Sintaksis Bahasa Kemak". Hibah Penelitian Disertasi Doktor: Universitas Udayana.

Comrie, B. 1983, 1989. Language Universal and Linguistic Typology. Oxford: Basil Blackwell.

Comrie, B. 1983, 1989. “Linguistic Typology". Dalam Newmeyer, F. J. (Ed.) Linguistics : The Cambridge Survey. Vol I. Hal : 447--467. Cambridge: Cambridge University Press..

Darlymple, Mary. 2001. Lexical Functional Grammar (Syntax and Semantic Vol. 34). Oxford: Oxford University Press.

Djajasudarma, T. Fatimah. 1993a. Metode Linguistik: Ancangan Metode Penelitian dan Kajian. Bandung: Eresco.

Keenan, Edward. 1976. “Towards A Universal Definition of "Subject: In Subject and Topic. Charkles Li (Ed).

Kridalaksana, Harimurti. 1993. Kamus Lingusitik. (Edisi Ketiga).Jakarta: Penerbit PT Gramedia.
Mandaru, A. Mans., Haan, John W., Liufeto, G. 1998. Morfologi dan Sintaksis Bahasa Kemak. Jakarta: Pusat Pembinaan dan Pengembangan Bahasa.

Mithun, Marrianne. 2001. "Who Shapes the Record, the Speaker and the Linguist".Dalam Newman, Paul and Martha Ratliff, Editors. Linguistics Fieldwork. First Edition. Cambridge: Cambridge University Press.

Palmer, F. R. 1994. Grammatical Roles and Relations. Cambridge: Cambridge University Press.

Sadnyana, I Nengah Semeta., Sutama, I Putu., Sunihati Anak Agung Dewi., Aridawati, Ida Ayu Putu. 1996. Struktur Bahasa Kemak. Jakarta: Pusat Pembinaan dan Pengembangan Bahasa

Song, J. J. 2001. Linguistic Typology: Morphology and Syntax. Harlow, England:Pearson Education Limited

Stevens, Alan M. 1967. Kemak: An Austrinesian Language. Dalam Anthropological Linguistics Vol 9. No 1. Januari 1967. Hal: 26 - 32.

Sudaryanto. 1993. Metode dan Aneka Teknik Analisis Bahasa. Yogyakarta: Duta Wacana University Press.

Verhaar, John W. M. 1996. Asas-Asas Linguistik Umum. Yogyakarta: Gadjah Mada University Press.

Yusdi, Muhammad. 2008. "Interaksi Topik Gramatikal dengan Pragmatik dalam Bahasa Indonesia" Dalam Lingua Didaktika. Volume 2, 38-50. 